Criminal Justice Ethics

\title{
The Torture Debate and the Toleration of Torture
}

\section{Jessica Wolfendale}

To cite this article: Jessica Wolfendale (2019): The Torture Debate and the Toleration of Torture, Criminal Justice Ethics, DOI: 10.1080/0731129X.2019.1638611

To link to this article: https://doi.org/10.1080/0731129X.2019.1638611

\section{Published online: 21 Aug 2019.}

Submit your article to this journal $\pi$

\section{!II Article views: 4}

Q View related articles $\widetilde{ }$

View Crossmark data $\nearrow$ 


\section{The Torture Debate and the Toleration of Torture}

\section{JESSICA WOLFENDALE*}

Anderson, Scott A. and Martha C. Nussbaum, eds. Confronting Torture: Essays on the Ethics, Legality, History, and Psychology of Torture. Chicago: University of Chicago Press, 2018. 356 pp., 35.00 (paperback), ISBN 9780226529417

\section{Introduction}

One of the questions raised by this important and thought-provoking collection of essays on torture is how and why the consensus that torture is wrong-a consensus enshrined in international law for decades-has become so fragile. As Scott Anderson writes in the introduction to this volume, "[h]ow did abusing and torturing prisoners suddenly become so popular?" (2). The chapters in this volume offer insights into this question from the perspectives of history, psychology, law, philosophy, and sociology. This interdisciplinary approach highlights important and often overlooked aspects of the torture debate. Yet, the questions that the authors take to be important (for example, about whether the justification of torture should even be contemplated) reflect different and

*Jessica Wolfendale is Professor of Philosophy at Marquette University, Milwaukee, WI, USA. Email: Jessica.Wolfendale@ marquette.edu sometimes incompatible normative assumptions about what torture is and about what matters in the torture debate. These assumptions, I shall argue, are shaped by, and play a role in shaping, the moral, political, and social narratives that contribute to or resist the toleration of torture in the US and elsewhere. Thus, while the disparate nature of the contributions (perhaps inevitably) undermine the cohesiveness of the volume as a whole, it illuminates, even if it does not resolve, larger questions about the place and function of academic debate in the history and use of torture.

In this essay I use the chapters in this volume as a starting point to explore the connection between the torture debate and the toleration of torture. In section I, I consider why the justification of torture is a matter for debate at all. What do we learn by contemplating hypothetical cases of justified torture, such as those discussed by Jeff McMahan and David Sussman in 
their chapters? I argue that the assumption that torture is "on the table" reflects the fact that torture is already part of our social imagination in a way that is not true of other acts of brutality, such as rape. Section II examines why we are willing to contemplate, construct, and publicly defend cases of justified torture but not cases of justified rape. I argue that the individualized torture narrative that informs much of the debate about torture-the depiction of torture as a single act against a guilty individual, performed solely for the "pure" motive of saving lives-distorts our understanding of what torture is and reinforces and masks multiple levels of torture toleration in US society. To understand the toleration of torture, we must start not from a supposedly neutral consideration of hypothetical cases, but by learning about the reality of torture. Section III examines what we can learn about torture from the accounts of torture and torture practices found in this volume: about the nature of torture, the purposes of torture, the victims of torture, and the narratives and institutional structures that sustain the use of torture. Finally, in section IV, I suggest that the chapters in this volume help illuminate how torture in the US is tolerated both directly, through intentional policies and practices, and indirectly, through institutional structures and political and legal narratives which enable torture to occur. This analysis of different levels of torture toleration reveals how deeply torture is embedded within US history and institutions, and how this toleration is sustained and reinforced by certain ways of thinking and talking about torture.

\section{Why Are We Debating Torture?}

To begin, I want to consider the question raised in the first chapter in the volume, by Albie Sachs: why is torture a matter for debate at all? What are we hoping to learn from arguing about whether torture could be permissible? What kind of questions should we be asking about torture? Sachs, a survivor of torture in South Africa, describes the shock of hearing a philosopher apply a cost-benefit analysis to the question of torture. In Sachs's view, to dedicate time and energy to debating the justification of torture is like "weighing up the pluses and minuses of slavery or blackmail or child abuse" (21). As he notes, it is unlikely that academic debates about the justifiability of torture would be held in countries that had actually experienced systematic torture, such as Chile, Argentina, or South Africa. Sachs is suggesting that to consider such a debate as reasonable and worthy of a public platform - to view torture as "on the table," even hypothetically - represents a failure to understand what torture does to victims, to torturers, and, indeed, to the state itself. In his view, to engage in such a debate is to give credence to a position that simply should not be up for discussion.

Sachs's essay raises a question about privilege, knowledge, and ignorance. On the one hand, to be able to contemplate, write, and talk about torture as a purely hypothetical possibility (and to be invited to public platforms in which to do this, such as 
the conference from which this book resulted) represents a kind of social and moral privilege in the sense that a person invited to speak about the ethics of torture is accorded the status as an expert on the morality of torture. ${ }^{1}$ But it also reflects a privileged ignorance, because it presumes that we can (and perhaps should) debate torture in a way that is abstracted from the realities of torture. But this presumption is based on ignorance about the nature and purposes of torture and the reality of torture in the US, and a failure to see the victims of torture. Torture in the US is not and never has been a matter of merely hypothetical debate. Instead, torture is embedded in US history and institutions, including the institutions of slavery, punishment, and national security. Assuming that we can start the debate about torture from a supposedly objective consideration about whether torture can be justified-and assuming that torture can be used for just purposes only against those who are morally liable to torture, as Jeff McMahan does in his chapter in the volume (197)fosters this privileged ignorance by cultivating the pretense that the debate about torture is a debate about what we might do, and not a debate about what we have done.

\section{Defenses of Debating Torture}

Jeff McMahan defends the value of using hypothetical cases to debate the ethics of torture in his chapter "Torture and Method in Moral Philosophy." McMahan hypothesizes that Sachs's opposition to debating torture is appealing because Sachs is innocent: "The effectiveness of Sachs' descriptions [of torture] would be lost, not if they referred to hypothetical circumstances, but if the victim were clearly not innocent and the aims of the torturers were clearly just" (197). McMahan argues that hypothetical cases of justified torture can serve important theoretical goals, such as helping us understand why torture is objectionable (205). In McMahan's view, our intuitions about hypothetical cases support a liability-based (rather than a utilitarian) justification of torture in ticking bomb cases: the terrorist has made himself liable to be tortured by his moral responsibility for a continuing threat of serious harm that only torture can prevent (200). ${ }^{2}$

David Sussman also criticizes absolutist positions on torture in his chapter "Torture, Self-Defense, and Fighting Dirty." Drawing on Thomas Nagel's distinction between "clean" and "dirty" fighting in war (220), ${ }^{3}$ Sussman suggests that torture appears to be a quintessential example of "dirty fighting" because it is directed at the victim's person and forestalls the "relations of mutuality and reciprocity" involved in treating the victim as a subject (229). However, Sussman argues that torture may still be permissible in order to "frustrate an act of terrorism or torture already in progress" if there are no other reasonable options, because in such a case the wrongful acts to which torture is responding have already made reciprocity and "full reconciliation morally impossible" (228,230). Both McMahan and Sussman, then, link the permissibility of torture to the torture victim's wrongful acts and how those wrongful acts alter the moral framework of torture. Both authors argue that constructing hypothetical cases of permissible torture is valuable, even if such cases might be extremely rare. 
Yet Sussman's and McMahan's defenses of debating torture (and the use of hypotheticals to do so) is not convincing. Firstly, McMahan describes Sachs's argument as "essentially a sustained appeal to moral sentiment" (196), yet himself appeals to "moral sentiment" to justify his refusal to consider whether torture as punishment could be justified: "I find the view ...that people can deserve to be tortured deeply repellant" (211). This dismissal sits uneasily with his rejection of moral absolutism about torture. If contemplating ticking bomb cases helps us understand what is objectionable about torture, as McMahan claims, why couldn't we learn important information about torture through contemplating cases of justified torture as punishment? It doesn't seem far-fetched to imagine a person whose crimes are so horrendous that they deserve torture, even if we don't think the state should necessarily inflict torture as a punishment. But since McMahan offers no argument in support of the "deeply repellent" idea that "people can deserve to be tortured," we are no closer to understanding what it is about torture that explains why it is so "deeply repellant." Thus, though McMahan argues that hypothetical cases can teach us what is objectionable about torture, in fact we do not learn anything about the nature of torture from his examples. We do learn that some people believe that it's permissible to torture a guilty terrorist, but this does not tell us anything important about the morality of torture, since, while desert claims and liability claims are different (as McMahan notes [211]), it is not obvious that people's intuitions are reliably tracking liability judgments rather than desert judgments.

Marcia Baron addresses a second problem with defenses of ticking bomb hypotheticals in her chapter "The Ticking Bomb Hypothetical." Initially, the idea that any ethical questions should not be debated (or at least not given a public platform) seems contrary to the value of free speech and academic debate. And yet we do treat some morally atrocious acts as not up for debate, such as rape. We do not think, for example, that an academic conference on sexual violence ought to, in the interest of presenting "both sides," invite speakers to defend the possibility of justified rape. As Baron points out:

We are expected to be prepared to answer questions about whether we would torture, or want others to torture, in a ticking bomb scenario, yet are not expected to answer questions about whether we would be willing to rape someone, or order or abet a rape, if that were necessary to prevent a catastrophe of massive proportions (193).

So, why is constructing and defending cases of permissible torture viewed as a legitimate contribution to the torture debate that warrants a public platform (invitations to present at conferences, contribute to edited collections, and so forth), but constructing and defending cases of permissible rape is not? The answer cannot be that the ticking bomb hypothetical is "more realistic than most," as McMahan suggests (198). Firstly, some authors question whether any real-life cases could meet the highly specified conditions of the ticking bomb scenario, ${ }^{4}$ but even defenders of torture concede that the odds of a real-life case meeting the criteria of justified 
torture are very low. Their defense of hypotheticals doesn't rest on the claim that such cases are likely to occur in real-life. For example, the likelihood of a real-life case fitting Sussman's description of an instance of permissible torture-where torture is necessary to prevent an already-occurring instance of torture -is vanishingly small. Instead, the use of hypothetical cases is defended on the grounds that they help illuminate important moral distinctions and reveal problems with moral absolutism. Yet, if the main point of these cases is to illustrate such theoretical points, it is worth asking why McMahan and Sussman (and others who defend torture using hypothetical cases) never use hypothetical cases of justified rape, even though such cases would serve their theoretical purposes equally well. Sussman implicitly acknowledges this when, in his rejection of absolutism, he points out that "similar to rape, it is hard (though not impossible) to devise a moderately realistic scenario in which tangible predicted benefits of torturing would outweigh the badness of the act itself" (233, my italics). Sussman thereby acknowledges that it would be possible to create a hypothetical scenario in which rape might be permissible, even justified.

Secondly, sexual violence is a frequently used torture method. Defenders of torture can't rule out sexual violence as a torture method without falling afoul of the moral absolutism they reject. McMahan and Sussman (and others who take similar views) are, by defending torture, also defending the possibility that rape can be used as a form of torture. We are therefore warranted in inquiring further into why the ethics of torture are up for debate while the ethics of rape are not, and why defenses of torture are given academic, legal, and political airtime when defenses of rape are not. Answering this question will, I suggest, help us answer the question raised by Scott Anderson in the introduction to the volume: Why are we so willing to entertain the possibility of torture?

\section{Contemplating Torture and Tolerating Torture}

Marcia Baron hypothesizes that we are willing to contemplate the possibility of justified torture but not justified rape because "we are still bedeviled into thinking that torture is generally effective... We have not fully abandoned the idea that torture will work when nothing else will" (193). In his chapter on the history of US torture of prisoners of war, Christopher Einolf also references a belief that torture "was useful" as a partial explanation for the use of torture (121). Yet, a belief in torture's efficacy does not explain our willingness to contemplate justified torture. Firstly, there is consistent and compelling evidence that torture doesn't work. ${ }^{5}$ In their chapter "Police Interrogation and Coercion in Domestic American History: Lessons for the War on Terror," Richard Leo and K. Alexa Hoenig demonstrate that torture not only failed to produce reliable information during the War on Terror (165), but false intelligence gained from torture also "wasted US resources as false leads were 
pursued" (169). Indeed, information gained under torture has led to the torture of innocent people, as occurred to the two men falsely accused by Khalid Sheik Muhammed under torture. ${ }^{6}$ Torture's unreliability was recognized very early in the history of torture. As Kathleen Coleman points out in her chapter "The Fragility of Evidence: Torture in Ancient Rome": "while torture was thought to be a means of securing truth, at the same time-paradoxically-it was recognized that it was likely to produce falsehoods and injustice" (107). The discrepancy between the persistent belief that torture could work and the actual (and well-documented) failure of torture to reliably produce good information and true confessions suggests that, despite appearances, the continued support for the contemplation of justified torture has little to do with objective assessments about torture's effectiveness.

\section{Torture and State Power in the Social Imagination}

A willingness to devote time and energy to the construction of hypothetical cases of justified torture, and to publishing and defending such cases, reflects a willingness to imaginatively tolerate torture in a way that does not appear to be true of rape. ${ }^{7}$ Now, those who defend cases of justified torture will (rightly) object that the creation of hypothetical cases of justified torture does not imply support for any existing torture practices. True, but the same could be said about constructing, defending, and publishing cases of justified rape. Yet, the mere willingness to devote time and energy to constructing and defending cases of justified rape would, I suspect, be viewed as deeply problematic (indeed, "deeply repellant," to borrow McMahan's phrase) quite independently of whether or not we took such cases to apply to any real-life instances of rape.

Here, one might point out that the scale of sexual assault against women and the lack of severe punishment for perpetrators suggests that we do tolerate rape. This is undoubtedly true. However, the difference between our toleration of torture and our toleration of rape has to do with the context in which the torture debate occurs. The torture debate overwhelmingly focuses on the context of terrorism - a fact reflected in the nature of the hypotheticals used to defend torture. The imaginative toleration of torture thereby reflects and reinforces background assumptions about the scope of a state's right to use force to defend itself from perceived threats. These background assumptions give a veneer of legitimacy to the question of torture that does not apply to the question of rape. While we tolerate rape in our society, we do not see rape as within the range of legitimate state forms of violence and so we don't tolerate the construction and defense of theoretical cases of justified rape within academic, legal, or political debate about the limits and purposes of state power. ${ }^{8}$

Another difference between our attitudes toward rape and toward torture lies in the status of the prohibition against torture in domestic and international law. In his chapter "Torture and Positive Law: Jurisprudence for the White House," Jeremy Waldron argues that the prohibition against torture represents a "legal archetype" that embodies and reinforces the view that law "is not 
brutal in its operation" (275). As David Luban argues, the historical connection between torture and tyranny means that liberal societies must frame the use of torture as the (tragic) choice of good people motivated only by the need to prevent disaster since this is the only motive for torture that is consistent with liberal values. ${ }^{9}$ Thus, it is no coincidence that the debate about torture in the US starts with the creation of hypotheticals in which torture is represented as an individual act (and not, as it actually is, a "socially embedded practice" ${ }^{\prime 10}$ ) against a guilty person for the purpose of saving lives. By shaping and rationalizing the toleration of torture, this individualized narrative of torture enables torture to become imaginatively possible, thereby masking the degree to which torture is embedded in US history and institutions. As I shall argue, the imaginative toleration of torture reflects and reinforces the actual direct and indirect toleration of torture in US society across a range of contexts in which state power is wielded, including national security contexts and within the criminal justice system.

Instead of starting the torture debate from the position of privileged ignorance that characterizes the individualized narrative of torture, we learn far more about the nature and purposes of torture from looking at the reality of torture. The reality of torture, as documented in several chapters in this volume, stands in stark contrast to the framing of the torture debate as representing a new and unprecedent choice, "a dramatic break from the past," as Leo and Koenig put it in their chapter (148). Instead, these accounts reveal that torture has been enmeshed in US police, military, intelligence, and even educational culture for decades, characterized by consistent and utterly predictable patterns of practice and justificatory narratives. We are willing to imaginatively tolerate torture because we do tolerate the use of torture by the state and our willingness to imagine cases of justified torture contributes to the fragility of the prohibition against torture.

\section{The Reality of Torture}

1. The Purpose and Impact of Torture Albie Sachs's chapter and William Gorman and Sandra Zakowski's chapter "The Many Faces of Torture: A Psychological Perspective" offer powerful testimony about the impact of torture on victims and the purposes of torture. For many of the victims described in Gorman and Zakowski's chapter, torture shatters "a fundamental sense of security and connection". The experience of torture is consistently described as "disempowerment and terrorization, a breaking of body and spirit, through the causation of mental and physical pain" (45). Sachs's account demonstrates how the use of torture is rarely about the pursuit of information-he describes being tortured by sleep deprivation despite the fact that any information he had at that point was two years old. So why was he tortured? "The battle was not even about information. It was about breaking me. It was about showing that they were stronger, that they were more powerful" (25). As Sanford Levison has argued, the 
phenomenology of torture, like that of slavery, is about creating "a phenomenological reality of total control."11 From the victim's perspective, torture expresses, in the clearest way possible, the torturer's refusal to acknowledge any limits on what may be done to a person. Similarly, a state's willingness to use torture represents a commitment to what Lisa Hajjar describes in her chapter "In Defense of Lawfare" as a "hyper-sovereigntist" (299) view of state power-the view that there ought to be no constraints on the state's right to use force to protect itself from perceived threats (300). Since this view of state power is antithetical to the liberal rejection of political tyranny, the justification of torture in democratic states aims to reconcile torture with this rejection of tyranny. ${ }^{12}$ Such a reconciliation is impossible, however, because torture is inherently a form of tyranny.

In contrast to the image of "torture motivated by just causes" that is the centerpiece of the individualized torture narrative, torture is intrinsically connected to breaking a person and demonstrating total domination over them. As Leo and Koenig explain, during the era of police torture known as the "third degree, ${ }^{13}$ the purpose of torture was "forcing confessions" (154). It didn't matter whether the confession was true or not; what mattered was the existence of the confession. That the primary purpose of torture is "breaking" victims is also clear from training manuals for torturers. The CIA's KUBARK Counterintelligence Interrogation manual, for example, praises techniques such as extended sleep deprivation, manipulation of noise and heat, and forced standing on the grounds that these methods are "devastatingly effective" in breaking down prisoners' mental and physical integrity. ${ }^{14}$ The aim to "break" victims - to deliberately use pain and distress to disempower and terrorize a person who is helplesscannot be separated from the "pure" aims of gaining information. To pretend that these aims can be separated-that there could a case of "pure" interrogational torturedemonstrates precisely the privileged ignorance I discussed earlier. This becomes even clearer when we examine the contexts in which torture has been used in the US.

\section{The Practice and Justification of Torture}

The chapters by Leo and Koenig, Einolf, and Mary Ann Case describe, respectively, the use of torture in the contexts of law enforcement, combat, and in initiation rites in military schools and academies. Despite focusing on very different historical contexts, all three chapters reveal similarities in the narratives used to justify torture. The narratives and justifications used to defend torture take three common forms: appeals to exceptionalism, denial of the harm of torture, and delegitimization of torture victims.

\section{a) Appeals to Exceptionalism}

In the police and military context, the choice to use torture is frequently depicted as a (regrettable) necessity created by a new and unprecedented threat. For instance, Leo and Koenig describe how, during the time of the third degree, the concept of a "'new' kind of war ... permeated society" (162). References to a "new" kind of war were also used during the Bush Administration to justify the use of torture (161). Similarly, appeals to 
exceptionalism were used by US forces to justify the torture of captured prisoners in the Philippine War (1899-1902) and in the Vietnam War. ${ }^{15}$ Einolf hypothesizes that torture was used in these conflicts, but not during the Mexican War or the Civil War, primarily because these conflicts were framed as counterinsurgencies, involving guerilla fighters who were perceived as "illegitimate enemies" (135) who were "underserving of the protections that are due by law or custom" (136). Like Leo and Koenig, Einolf finds strong parallels between these justificatory narratives and the defense of torture offered during the Bush Administration's war on terror, and uses these parallels to critique these narratives (138-9). The claim that torture is a tragic choice forced upon good people facing new and terrible threats is also, as we have seen, characteristic of the individualized narrative of torture presented in many torture hypotheticals. This narrative thus reflects and reinforces the appeals to exceptionalism that permeate the actual practice of torture.

\section{b) Denial of the Harm of Torture}

A second common feature of justificatory narratives of torture is the denial that the methods used are torture. Case's, Leo and Koenig's, and Einolf's chapters reveal striking similarities in both the specific torture methods used in the different contexts they discuss, and in how the harm of these methods is minimized. Leo and Koenig note striking similarities between the torture methods used during the third degree and those used in the war on torture, including extended sleep deprivation, threats of harm, temperature manipulation, and noise bombardment (160). Einolf describes how the use of the "water torture" during the Philippine War was dismissed as not "real" torture (138). Case identifies strong similarities between the abuses at $\mathrm{Abu}$ Ghraib prison and the humiliations inflicted during hazing rituals in military academies and fraternities and highlights the gendered implications of these methods, such as the "use of feminization as a means of ... breaking individuals" (96-7). Some commentators used the similarity between hazing rituals and the abuses at Abu Ghraib to dismiss the severity of detainee abuse. Rush Limbaugh, for example, claimed that the abuse of detainees "was hazing, it was an out-of-control fraternity prank" (91). The minimization of the harm of torture serves two related purposes. Firstly, it alleviates the moral responsibility of the torturers by enabling the illusion that what they are doing is not "really" torture, and, secondly, it helps to reconcile the use of torture with liberal moral and political commitments by drawing a (false) distinction between "real" torture and torture "lite" or "enhanced interrogation." 16

\section{c) Delegitimization of Torture Victims}

The history of torture and the testimony of torture victims reveals that the denigration of victims is crucial to understanding the toleration of torture. The point is not that torture victims are dehumanized through being tortured-although that is clearly true-but rather that torture becomes imaginatively possible only in relation to those who are already delegitimized. As Scott Anderson argues, democratic states like the US resort to torture primarily against "people who are regarded as quite distinct from the dominant ethnic/racial/religious 
groups doing the torturing" (245). In contrast to the individualized narrative of torture, in which torture is a single act against a person who is morally responsible for harm, in reality torture victims are selected not because of their actions but because of their membership in a torturable class. The membership of a potential torture victim in a "torturable" class is necessary because the use of torture requires a refusal to see the victim's status as a person as setting limits on what may be done to them. The history of torture reveals that those who were initially classified as "torturable" were already viewed as having lesser moral standing. It was permissible to torture them not primarily because of what they had done or because of information they might possess, but because of who they were. Torture thereby serves to reinforce and reinscribe (literally on the body of torture victims) distinctions in the moral, social, and political status of those who may be tortured and those who may not. For example, in Ancient Rome, as Kathleen Coleman points out, torture was (at first) only permitted on slaves (105). In Medieval Europe, Leo and Koenig note, torture was not permitted against "children, the elderly, pregnant women, knights, barons, aristocrats, kings, professors, and ... the clergy" (167). ${ }^{17}$ In Italy in the late Middle Ages, torture was only permitted against noncitizens and slaves-"[c]tizens had dignity and were thus inviolable." 18 This demonstrates that the choice to use torture is not based on a belief in torture's efficacy in producing information or confessions, but rather reflects and reinforces the pre-existing moral exclusion of some groups from the normative status that would make torturing them unthinkable.
Yet, the restriction of torture to a class of torturable victims is rarely, if ever, maintained. In Rome, the class of those who could be tortured widened to include "lower-end citizens, the humiliores, and in time, the emperors did not care about anyone's civic immunity." ${ }^{19}$ A similar pattern occurred in Italy, where eventually "citizens also could be tortured if they were of bad moral reputation." ${ }^{20}$ Leo and Koenig describe how the use of torture expanded during the war on terror. While secret renditions were initially limited to a small class of prisoners, "it quickly spread to include a much wider and ill-defined population that the administration termed 'illegal enemy combatants'" (167). The expansion of the class of torture victims is utterly predictable. Once no limits are acknowledged to apply to state power over individuals, little stands in the way of expanding the boundaries of such power.

The narratives and justifications described above play an important role in legitimizing and normalizing torture, and in making the use of torture appear consistent with democratic purposes and values. Here we can see the intersection between these narratives and the individualized narrative of torture created and sustained through the use of hypothetical cases. It is no accident that these hypothetical cases reflect and reinforce a narrative of torture very similar to the narratives that accompany and normalize the actual practice of torture. Indeed, far from being a merely academic thought experiment, reference to hypothetical cases has played an important role in the legal and political justification of torture in democratic states and in fostering public acceptance of torture. For example, in 1999, the Israeli Supreme 
Court ruled that torture was illegal, but that security officials accused of torture could plead necessity in ticking time-bomb cases. ${ }^{21}$ In the US, reference to ticking bomb-type scenarios appears in the August 1, 2002 memo on the "Standards of Conduct for Interrogation" prepared by the Office of Legal Counsel for the White House. The memo argues that the necessity defense could be available to military personnel charged with torture in circumstances very like those that characterize standard torture hypotheticals:

\section{A detainee may possess information that could enable the United States to prevent attacks that potentially could equal or surpass the September 11 attacks in their magnitude. Clearly, any harm that might occur during an interrogation would pale to insignificance compared to the harm avoided be preventing such an attack. $^{22}$}

Thus, the individualized narrative of torture is not a harmless philosophical thought experiment: it has a real impact on the ways in which torture is practiced and justified.

There is a further way in which the individualized narrative of torture distorts our understanding of the reality of torture. By forcing our attention onto a narrow and highly abstract picture of torture, the individualized narrative excludes consideration of the broader moral, political, and social framework in which actual torture flourishes and instead drives the debate into positions of either defending or refuting the individualized narrative. This means that we fail to examine torture in contexts beyond the narrow discussion of torture and terrorism and fail to consider the possibility that institutional practices and systems can create torture practices that are not the product of intentional policies or individual decisions. In the final section, I explore what it would mean to expand our thinking about torture in these ways.

\section{Two Levels of Torture Toleration}

The chapters in Confronting Torture expose the scope of torture toleration in the US and elsewhere. We see evidence of the acceptance and proliferation of torture within the criminal justice system, the legal profession, the police force, the military, and intelligence services. However, more can and needs to be done to truly understand the nature of torture toleration in the US. In this last section, I extend the question about what torture is beyond the scope of this volume to show how torture toleration takes place on at least two distinct levels.

\section{Direct Torture: Torture as Policy and Intentional Act}

The chapters in Confronting Torture primarily focus on torture as part of a deliberate policy: torture against terrorism suspects, captured prisoners, criminal suspects, and political opponents. As I outlined in Section III, the justificatory narratives of such torture are characterized by appeals to exceptionalism, denial of the harm of torture, and the creation of a class of torturable victims. Such uses of torture are typically justified by reference to supposedly legitimate state purposes, such as protecting the 
state from threats to national security. In reality, however, these forms of state torture reinforce differential moral statuses among groups (the difference between those who may be tortured and those against whom torture cannot be contemplated) and express, in the clearest possible way, a rejection of limits on state power.

There is another context in which torture as a deliberate policy occurs, which is, unfortunately, not addressed in any detail in Confronting Torture: torture as punishment. ${ }^{23} \mathrm{~A}$ number of authors have argued persuasively that solitary confinementa practice common in US prisons - is a form of torture. ${ }^{24}$ Like the use of torture against terrorism suspects, the use of solitary confinement represents an expression of total state power over the individual and reinforces and reflects the diminished moral status of prisoners - disproportionately prisoners of color-who are subjected to it. ${ }^{25}$ Torture in the terrorism context is justified by claims that those subject to it are morally liable to be tortured, which masks the way in which torture operates to select and reinforce the demeaned moral status of torturable groups. Likewise, the common justification of solitary confinement as deserved punishment for the "worst of the worst" ${ }^{26}$ masks the moral exclusion of those groups subjected to it. This suggests that there are important connections between the function of torture and the justificatory narratives that sustain the use of torture in the security context and in the context of punishment that have been insufficiently explored in the torture debate.

Torture as policy and practice is the most visible form of torture toleration in the US. Hence, it is not surprising that the torture debate has focused almost exclusively on this kind of torture. However, one of the effects of this narrow focus is a failure to consider the possibility that torture can occur in the absence of direct intention. Because the torture debate tends to devolve into defenses of or responses to the individualized narrative of torture, a kind of "tunnel vision" results regarding what torture is and the context in which torture occurs. By contrast, if we don't start with the assumption that torture must be the result of direct intention, we have room to explore the possibility that torture can occur in a broader range of contexts. Torture can occur indirectly, in the context of what I call torturous institutions.

\section{Indirect Torture: Torturous Institutions}

A tortuous institution is an institution in which acts that constitute torture are permitted to occur, even if they are not part of institutional policy or practice. The prison system in US society is an example of a torturous institution. The US prison system is an institution in which intentional torture occurs (the use of solitary confinement) and in which torture is allowed to occur. Prison rape and sexual assault (perpetrated by prisoners against other prisoners, and by guards against prisoners) is common in US prisons, to such an extent that it is taken for granted-prison rape is the subject of jokes and threats by police officers and is regularly mentioned in depictions of prison in popular culture. ${ }^{27}$ Sexual violence is, as I noted earlier, a form of torture. Sexual violence against prisoners meets the definition of torture not 
only because of the suffering inflicted by sexual violence but because the victim is a prisoner. $^{28}$ It is indirect torture because while sexual assault is not part of an intentional policy, the failure at both the institutional and policy level to seriously tackle sexual violence in prison indicates that such sexual violence is willingly tolerated. ${ }^{29}$ This toleration is further reinforced by the lack of public concern for this issue. As with the justificatory narratives of torture discussed earlier, prison sexual abuse is rarely described as torture, and the victims are rarely believed but are demeaned or ignored. ${ }^{30}$ Arguably, as with attitudes toward intentional torture, the toleration of prison rape and the denigration of victims expresses the devalued status of the victims, a status that is taken to license and excuse their treatment. This raises the possibility that the toleration of sexual abuse of prisoners serves a similar function to the use of intentional torture: it reinforces and reinscribes the moral devaluation of prisoners that is already a central aspect of the US prison system.

\section{Conclusion}

Direct and indirect torture serve related purposes connected to the demeaned moral status of the victim and the expression of state power. Exploring these connections and developing a deeper understanding of the forms of torture and the ways in which institutional practices, academic debate, and narratives of torture sustain different forms of torture toleration, is an essential next step in the torture debate. The interdisciplinary nature of the chapters in Confronting Torture offers a valuable starting point in this process by providing insights into the nature of state torture, but also reveals some of the problems with the way the torture debate has traditionally been framed around an individualized narrative. Thus, what is missing from the volume helps us see what further questions need to be asked about the toleration of torture.

\section{Notes}

1 I thank Margaret Urban Walker for her helpful comments on this section.

2 I won't address McMahan's theory of liability to defensive harm here. However, Scott Anderson notes at least one problem with McMahan's view in his chapter "Torture as an Unjust Means of War." Anderson argues that McMahan's view collapses the distinction between combatant and civilian that is a cornerstone of international law on armed conflict (247 n30).

3 While both McMahan and Sussman criticize moral absolutist positions on torture, they defend a legal absolutist position on torture. Sussman, for example, argues that "states have reasonably agreed to ban the use of torture in international law because it is a barbaric act that is predictably counterproductive to the aims for which a war may be justly fought" (237).

4 Baron makes this argument in her chapter, for example. See also Luban, "Liberalism," and Wolfendale, "Training Torturers."

5 See O'Mara, Why Torture Doesn't Work and Schiemann, Does Torture Work? for compelling evidence of the inefficacy of torture.

6 See Schiemann, Does Torture Work?, 224. 
7 Here I am drawing on Iris Young's discussion of violence in the social imagination. In "Five Faces of Oppression," Young argues that "[v]iolence is a social practice. It is a social given that everyone knows happens and will happen again. It is always at the horizon of social imagination, even for those who do not perpetrate it... The idea of rape will occur to many men who pick up a hitch-hiking woman; the idea of hounding or teasing a gay man on their dorm floor will occur to many straight male college students" (27). Young's point is that our attitudes towards violence, and the kinds of violence we see as inevitable or even normal (like the sexual assault of a hitch-hiking woman) are a product of what we are willing to tolerate and thus see as imaginatively possible.

8 I thank Theresa Tobin for raising this point and for her helpful comments on this paper.

9 See Luban, Torture, Power, and Law, 56.

10 Gordon, Mainstreaming Torture, 7.

11 Levinson, "Slavery," 151. See also Scarry, The Body in Pain and Sussman, "What's Wrong with Torture?"

\section{See Luban, Torture, Power, and Law.}

13 The era of the "third degree" refers to a period of time during which police brutality against criminal suspects was widespread, from roughly the end of the nineteenth century to the mid-1930s. See Leo and Koenig's chapter for a detailed discussion of the history and end of the third degree.

14 See McCoy, A Question of Torture, 49.

15 Einolf excludes torture against slaves, and the rape and abuse of Native American populations from his analysis. In fact, he argues that despite "many reports of violence against noncombatants, including rape, the massacre of prisoners, mutilation of bodies, and taking body parts as trophies" there is "almost no evidence of torture" by US troops against Native American tribes (124). This suggests that Einolf is using a very narrow definition of torture, although he does not make this clear.

16 See Wolfendale, "The Myth of Torture Life."

17 Leo and Koenig cite Conroy, Unspeakable Acts, Ordinary People, 29-30.

18 Rejali, Torture and Democracy, 50.

19 Ibid., 527. See also Coleman's chapter.

20 Rejali, Torture and Democracy, 50.

21 See Luban, Torture, Power, and Law, 81-2.

22 Cole, The Torture Memos, 92.

23 Waldron does mention the prohibition of torture in prison as part of his argument about the centrality of the prohibition against torture in US law (276-7).

24 See Conley, "Torture in US Jails"; Guenther, Solitary Confinement; and Kerness, "Torture in US Prisons."

25 See Flagg et al., “Who's in Solitary Confinement?"

26 Guenther, Solitary Confinement, 162.

27 See Femifesto, “Debunking Myths About Rape" and Bruenig, "Why Americans Don't Care."

28 See Waldron's chapter "Torture and Positive Law," 277 n.69.

29 What I say could also apply to the institutional toleration of other forms of prisoner mistreatment that amount to torture, such as the denial of food, and exposure to extreme heat or cold.

30 See Femifesto, "Debunking Myths About Rape."

\section{Bibliography}

Bruenig, Elizabeth Stoker. 2015. “Why Americans Don't Care About Prison Rape and What Happens When the Problem Escapes from Behind Bars." The Nation, March 2. https:// www.thenation.com/article/why-americansdont-care-about-prison-rape/.
Cole, David. The Torture Memos: Rationalizing the Unthinkable. New York: The New Press, 2009.

Conley, Anna. "Torture in US Jails and Prisons: An Analysis of Solitary Confinement Under International Law." Vienna Journal on 
International Constitutional Law 7, no. 4 (2013): 415-53.

Conroy, John. Unspeakable Acts, Ordinary People: The Dynamics of Torture. Berkeley: University of California Press, 2000.

Femifesto. 2016. "Debunking Myths About Rape in Prison." Huffpost, November 15. https:// www.huffingtonpost.ca/femifesto/mythsrape-prison_b_12951074.html.

Flagg, Anna, Alex Tatusian, and Christie Thompson. 2016. "Who's in Solitary Confinement?" The Marshall Project, November 30. https://www.themarshall project.org/2016/11/30/a-new-report-givesthe-most-detailed-breakdown-yet-of-howisolation-is-used-in-u-s-prisons.

Gordon, Rebecca. Mainstreaming Torture: Ethical Approaches in the Post 9/11 Era. New York: Oxford University Press, 2014.

Guenther, Lisa. Solitary Confinement: Social Death and its Afterlives. Minneapolis: University of Minnesota Press, 2013.

Kerness, Bonnie. "Torture in US Prisons." Peace Review: A Journal of Social Justice 23, no. 3 (2011): 364-8.

Levinson, Sanford. "Slavery and the Phenomenology of Torture." Social Research 74, no. 1 (2007): 149-68.

Luban, David. Torture, Power, and Law. New York: Cambridge University Press, 2014.

Luban, David. "Liberalism, Torture, and the Ticking Bomb." In The Torture Debate in
America, edited by Karen J. Greenberg, 3584. New York: Cambridge University Press, 2006.

O'Mara, Shane. Why Torture Doesn't Work: The Neuroscience of Interrogation. Harvard: Harvard University Press, 2015.

McCoy, Alfred W. A Question of Torture: CIA Interrogation, from the Cold War to the War on Terror. New York: Henry Holt, 2006.

Rejali, Darius. Torture and Democracy. Princeton, NJ: Princeton University Press, 2007.

Scarry, Elaine. The Body in Pain: The Making and Unmaking of the World. New York: Oxford University Press, 1985.

Schiemann, John W. Does Torture Work? New York: Oxford University Press, 2016.

Sussman, David. "What's Wrong with Torture?" Philosophy \& Public Affairs 33, no. 1(2005): 1-33.

Wolfendale, Jessica. "The Myth of Torture Life." Ethics and International Affairs 23, no. 1 (2009): 47-61.

Wolfendale, Jessica. "Training Torturers: A Critique of the 'Ticking Bomb' Argument." Social Theory and Practice 32, no. 2 (2006): 269-87.

Young, Iris. "The Five Faces of Oppression." In Diversity, Social Justice, and Inclusive Excellence, edited by Seth N. Asumah and Mechthild Nagel, 3-32. Albany: State University of New York Press, 2014. 